\title{
Wyjazd naukowy studentów Wydziału Prawa Kanonicznego Uniwersytetu Papieskiego Jana Pawła II w Krakowie do Rzymu (16-21 maja 2o15 roku) DOI: http://dx.doi.org/10.15633/acan.1087
}

W dniach od 16 do 21 maja 2015 roku studenci Wydziału Prawa Kanonicznego Uniwersytetu Papieskiego Jana Pawła II w Krakowie wraz ze swoim opiekunem - ks. dr. hab. Piotrem Steczkowskim oraz ks. dr. hab. Piotrem Kroczkiem, prof. UPJPII, odbyli wycieczkę naukową do Rzymu. Celem tego wyjazdu było zapoznanie się ze strukturą oraz funkcjonowaniem wybranych dykasterii Kurii Rzymskiej. Studenci prawa kanonicznego, mając teoretyczną wiedzę na temat pracy tej instytucji, mogli przede wszystkim zapoznać się z codzienną pracą trybunałów apostolskich oraz wybranych kongregacji. Dodatkowo w czasie wyjazdu udało się odwiedzić dwa uniwersytety papieskie posiadające wydziały prawa kanonicznego oraz Ambasadę Rzeczypospolitej Polski przy Stolicy Apostolskiej.

Pierwszym aktywnym dniem wyjazdu była niedziela 17 maja. Studenci wzięli udział we mszy świętej w kościele św. Stanisława BM; po jej zakończeniu udali się na Plac Świętego Piotra, by tam uczestniczyć w modlitwie południowej wraz z papieżem Franciszkiem.

Natomiast pierwszym z zaplanowanych na 18 maja spotkań była wizyta w Najwyższym Trybunale Sygnatury Apostolskiej. Jego siedziba - podobnie jak pozostałych trybunałów apostolskich - znajduje się w Palazzo della Cancelleria. Przybyłych powitał sekretarz NTSA abp Frans Daneels, O. Praem. Strukturę i sposób funkcjonowania tego trybunału przedstawił substytut (zastępca) promotora sprawiedliwości ks. prałat dr Paweł Malecha. Najwyższy Trybunał Sygnatury Apostolskiej działa w oparciu m.in. o motu proprio papieża Benedykta XVI z 21 czerwca 2008 roku Antiqua ordinatione o prawach własnych Najwyższego Trybunału Sygnatury Apostolskiej. W oparciu o ten dokument Sygnatura dzieli się na 3 sekcje: kasacyjną, administracyjną oraz o charakterze ministerstwa sprawiedliwości, która - jak podkreślił ks. Malecha - jest najważniejszą spośród wymienionych. Główne zadanie tej sekcji można określić jako sprawowanie kontroli nad prawidłowym funkcjonowaniem trybunałów kościelnych na całym świecie. Nadzór ten dokonuje się m.in. w oparciu o sprawozdania z działalności poszczególnych trybunałów, które są obowiązkowo przesyłane do Sygnatury za dany rok kalendarzowy, oraz poprzez examen sententiae, czyli sprawdzanie wyroków wybranych trybunałów. W Najwyższym Trybunale Sygnatury Apostolskiej pracuje aktualnie 13 osób, nie wliczając kardynałów sędziów. 
Drugim spotkaniem, które odbyło się tego dnia, była wizyta w Trybunale Roty Rzymskiej. Spotkaniu przewodniczył ks. dr Robert Gołębiewski, pełniący funkcję obrońcy węzła małżeńskiego. W Rocie Rzymskiej, która m.in. pełni funkcję trybunału apelacyjnego w Kościele katolickim, rocznie przyjmowanych jest ok. 785 spraw, z czego ok. 75 pochodzi z Polski. Aktualnie w Rocie Rzymskiej pracuje 20 sędziów, 3 obrońców węzła, 2 promotorów sprawiedliwości. Każdego dnia odbywa się od 2 do 3 przesłuchań. Sprawność pracy trybunału wynika m.in. ze specjalnych uprawnień, jakie ma on od lutego 2013 roku, oraz z funkcjonowania systemów komputerowych. Pierwszy z nich służy do digitalizacji akt wszystkich spraw napływających do Roty. Drugim z narzędzi znacznie przyspieszających procedurę jest system bieżącego zapisu głosu, który wykorzystywany jest w trakcie przesłuchań. Zeznania konwertowane są do formatu tekstu, dzięki czemu są one dostępne tuż po zakończeniu przesłuchania.

Ostatnią z odwiedzonych w tym dniu dykasterii rzymskich była Kongregacja Doktryny Wiary. Studenci spotkali się z pięcioma przedstawicielami tej dykasterii, spotkaniu przewodniczyli ks. dr John Kennedy oraz ks. dr Albert Warso. Kongregacja dzieli się na trzy sekcje: doktrynalną, dyscyplinarną oraz do spraw małżeńskich. W jej skład wchodzą również komisje: teologiczna, biblijna i Ecclesia Dei. Przy Kongregacji znajduje się archiwum, które jest prowadzone przez ks. Alberta Warsę. Zbiory archiwalne są odtajniane pontyfikatami kolejnych papieży.

Tego dnia studenci zostali również zaproszeni do zwiedzenia dwóch uniwersytetów papieskich znajdujących się w Rzymie.

Pierwszym z nich był Papieski Uniwersytet Gregoriański. O. prof. Janusz Kowal SJ zaprezentował pokrótce historię uniwersytetu, który został założony przez św. Ignacego Loyolę w 1551 roku. Papież Grzegorz XIII w 1584 roku erygował nową siedzibę uczelni i był jednocześnie jej opiekunem, stąd potoczna nazwa uniwersytetu - „Gregoriana”. Studenci mieli okazję zobaczyć m.in. bibliotekę uniwersytecką, mającą niezwykle bogaty księgozbiór, kaplicę znajdującą się na terenie uczelni oraz sale wykładowe i profesorskie.

Drugim z uniwersytetów papieskich było Angelicum, a więc Papieski Uniwersytet św. Tomasza z Akwinu. O. dr Piotr Skonieczny OP oprowadził studentów po uniwersytecie, na którym studiował m.in. Karol Wojtyła. W jednej z sal uniwersyteckich znajduje się niewielka wystawa poświęcona obecności przyszłego papieża na tym uniwersytecie. Znajdują się tam m.in. dokumenty poświadczające przyjęcie na studia oraz egzemplarz rozprawy doktorskiej Karola Wojtyły Doctrina de fide apud S. Ioannem a Cruce. Studenci mieli również okazję odwiedzić salę, 
w której Karol Wojtyła obronił rozprawę doktorską - jest to miejsce, w którym do dziś przeprowadza się obrony doktorskie. Wizyta w Angelicum zakończyła pierwszy aktywny dzień tego interesującego wyjazdu naukowego.

Kolejnego dnia pobytu, 19 maja, pierwszą z odwiedzonych dykasterii była Papieska Rada ds. Interpretacji Tekstów Prawnych (Pontificium Consilium de Legum Textibus) znajdująca się w Palazzo delle Congregazioni. Spotkanie prowadził kard. Francesco Coccopalmerio, przewodniczący Rady. Spotkanie odbyło się w tym samym pomieszczeniu, w którym powstał obowiązujący kodeks prawa kanonicznego. Przewodniczący Rady przedstawił pokrótce cztery obszary jej działalności, do których należą: legislacja, kontrola nad aplikacją ustawodawstwa kościelnego, interpretacja tekstów prawnych oraz działania na rzecz rozwoju prawa kanonicznego. Urzędowym pismem Rady jest „Communicationes” - półrocznik wydawany od 1969 roku. W ramach Rady działają dwie komisje pracujące nad reformą prawa karnego i prawa procesowego. Pierwsza z komisji zakończyła konsultacje schematu przyszłego dokumentu, aktualnie są rozpatrywane wniesione propozycje zmian (napłynęło 170 odpowiedzi z całego świata). Jak podkreślił kard. Coccopalmerio, drugi schemat co prawda mógłby zostać opublikowany, ale jeżeli reforma ta ma być pogłębiona, to należy dołożyć jeszcze większych starań, by ostateczny tekst był jak najbardziej precyzyjny. Problemem w dalszym ciągu pozostaje reforma części ogólnej prawa karnego. W kwestii reformy prawa procesowego istotą prowadzonych działań jest przyspieszenie procesu. Cel procesu pozostaje niezmienny - jest nim dotarcie do prawdy obiektywnej na temat danego małżeństwa. Przyspieszenie procedury mogłoby dotyczyć rezygnacji z wymogu dwóch zgodnych wyroków - pozostawiając naturalnie możliwość wniesienia apelacji. W sprawie reformy prawa procesowego działa również druga komisja - przy Rocie Rzymskiej.

Kolejnego dnia studenci odwiedzili trzeci z trybunałów Stolicy Apostolskiej - Penitencjarię Apostolską. Ks. dr Krzysztof Nykiel, regens Penitencjarii, przybliżył zakres kompetencji oraz sposób funkcjonowania tego „szczególnego” trybunału Kościoła. Obecnie pracuje w niej łącznie 12 osób, w tym 3 świeckie. Raz w miesiącu odbywają się spotkania z penitencjarzami z rzymskich bazylik. Aktualnie trwają prace nad przygotowaniem dekretu na temat odpustu na Rok Miłosierdzia, który został ogłoszony przez papieża Franciszka. Będzie się on składał z dwóch części: teoretycznej oraz zawierającej warunki uzyskania odpustu.

Następnie ks. Nykiel oprowadził studentów po archiwum Penitencjarii. Najstarsze znajdujące się tam dokumenty - które studenci mieli okazję zobaczyć - pochodzą z 1409 roku. 
Ostatnią z dykasterii, którą odwiedzili studenci, była Kongregacja Spraw Kanonizacyjnych. Jako pierwszy zakres pracy Kongregacji przedstawił ks. dr Bogusław Turek CSMA, jej podsekretarz. W procesie beatyfikacyjnym Kongregacja prowadzi tzw. etap rzymski. Ks. prałat Turek oprowadził zebranych po archiwum Kongregacji, w którym znajdują się tzw. positio (czyli summaria z materiałów przesłanych przez biskupów diecezjalnych, które zostały wydane w formie książkowej, począwszy od 1814 roku). Wcześniejsze dokumenty znajdują się w Bibliotece Narodowej w Paryżu. Archiwum ma również kompletną korespondencję prowadzoną przez Kongregację od roku 1588, a więc od powołania jej przez papieża Sykstusa V. W czasie wizyty studenci mieli możliwość zobaczenia kilku oryginalnych dokumentów w związku z procesami beatyfikacyjnymi. Były to m.in. list króla Jana Kazimierza wysłany do Rzymu w związku z beatyfikacją św. Stanisława Kostki, positio na temat cudu za wstawiennictwem Sługi Bożego Jana Pawła II. Następnie o. prof. Zdzisław Kijas OFMConv, który jest jednym z pięciu relatorów Kongregacji, przedstawił, w jaki sposób przebiega etap rzymski oraz jak powstaje positio. Kongregacja Spraw Kanonizacyjnych była ostatnią z dykasterii Kurii Rzymskiej, której codzienne funkcjonowanie studenci prawa kanonicznego mieli możliwość poznać.

Ostatnim z przewidzianych punktów była wizyta w Ambasadzie Rzeczypospolitej Polskiej przy Stolicy Apostolskiej. Pan ambasador dr Piotr Nowina-Konopka z ogromną życzliwością przyjął studentów i z zaciekawieniem przysłuchiwał się opowieściom na temat celu wizyty w Rzymie, jak również na temat samego prawa kanonicznego. Studenci mieli okazję wysłuchać historii polskiej ambasady przy Stolicy Apostolskiej, jak również dowiedzieć się, jakie działania są aktualnie podejmowane w ramach współpracy międzynarodowej. Pan ambasador opowiedział również zebranym o konferencji Kościót w chwili przełomu lat 8o. i 9o. w Europie Środkowo-Wschodniej (La Chiesa e la svolta degli anni 80/90 in Europa CentroOrientale), zorganizowanej przez ambasadę we współpracy z Papieską Akademią Nauk, która odbyła się 6 czerwca 2014 roku. Jako swoistą pamiątkę studenci otrzymali egzemplarze publikacji pokonferencyjnej, zawierającej zarówno wygłoszone przez uczestników prelekcje, jak również bogatą dokumentację fotograficzną $\mathrm{z}$ tego wydarzenia.

Ostatniego dnia pobytu w Rzymie studenci WPK wzięli udział we mszy świętej sprawowanej na grobie św. Jana Pawła II w Bazylice św. Piotra w Watykanie.

Wyjazd do Rzymu w celu zobaczenia centralnych instytucji Kościoła oraz poznania sposobu ich funkcjonowania, które studentom prawa kanonicznego są 
bardzo dobrze znane z teorii, był niezwykle ubogacającym doświadczeniem. Spotkania ze specjalistami na co dzień pracującymi na rzecz rozwoju oraz prawidłowej interpretacji prawa kanonicznego, wizyta w rzymskich ośrodkach naukowych, w których kształcą się przyszli kanoniści - wszystkie te doświadczenia pozwoliły jeszcze wyraźniej i z nieco innej - to znaczy z bardziej praktycznej strony - zobaczyć, czym jest oraz jaką rolę pełni w Kościele prawo kanoniczne.

Bogumiła Plewa 